\title{
Recommendations on screening for prostate cancer with the prostate-specific antigen test
}

\author{
Canadian Task Force on Preventive Health Care*
}

See related commentary on page 1201 and at www.cmaj.ca/lookup/doi/10.1503/cmaj.141252

$\mathrm{P}$ rostate cancer is the most commonly diagnosed non-skin cancer in men and the third leading cause of cancer-related death among men in Canada. ${ }^{1}$ The current estimated lifetime risk of diagnosis is $14.3 \%$, whereas the lifetime risk of death from prostate cancer is $3.6 \% .^{2}$ The prevalence of undiagnosed prostate cancer at autopsy is high and increases with age (> 40\% among men aged 40-49 yr to $>70 \%$ among men aged 70-79 yr). ${ }^{3}$ Most cases of diagnosed prostate cancer have a good prognosis; the 10 -year estimated relative survival ratio is now $95 \%$, the highest among all cancers in men. ${ }^{1}$

In Canada, the age-standardized rate of death from prostate cancer rose from 1969 to 1991 , followed by a decline of $37.5 \%$ from 1992 to 2009, at an average rate of $2.6 \%$ per year (Figure 1). In 1990, the estimated age-standardized mortality was 30 cases per 100000 , and in 2010 it was just below 20 per $100000 .{ }^{1}$ However, over the same period, the number of cases and the age-standardized incidence of prostate cancer both increased. Subsequent to the introduction and adoption of prostate-specific antigen (PSA) testing, the incidence of prostate cancer increased rapidly from 1990 to a peak in 1993 and a second, less-pronounced peak in 2001 (Figure 1). Much of the excess incidence represents overdiagnosis, ${ }^{4,5}$ that is, the detection of cancers that would not progress to cause symptoms or death. 6

There is no conclusive evidence to determine what proportion of the decline in prostate cancer mortality is due to screening versus improved treatment, or other factors; it is likely that both screening and treatment have contributed. ${ }^{7}$ If PSA screening were the primary reason for the decrease in mortality, the steep increase in incidence due to early case detection associated with screening should have been followed by a sharp reduction in mortality. Instead, the reduction in prostate cancer mortality over time has been relatively steady and began too soon after the test's introduction to be attributed mainly to PSA screening. ${ }^{7-10}$
This guideline provides recommendations on screening for prostate cancer using the PSA test with or without digital rectal examination in men in the general population. The guideline updates a prior guideline by the task force that was last published in $1994 .^{11}$

\section{Methods}

The Canadian Task Force on Preventive Health Care is an independent panel of volunteer clinicians and methodologists that makes recommendations about clinical manoeuvres aimed at primary and secondary prevention (www.canadian taskforce.ca). Work on each set of recommendations is led by a workgroup of two to six members of the task force. Each workgroup establishes the research questions and analytical framework for the guideline. More information about the task force's methods can be found elsewhere ${ }^{12}$ and on the task force website (http://canadiantaskforce .ca/methods/methods-manual/).

The development of these recommendations was led by a workgroup of six members of the task force and scientific staff at the Public Health Agency of Canada. Guideline development was based on an analytical framework (Appendix 1,

\section{KeY POINTS}

- The prevalence of undiagnosed prostate cancer at autopsy is high and increases with age (> $40 \%$ among men aged $40-49$ yr to $>70 \%$ among men aged 70-79 yr)

- Only a small proportion of men with prostate cancer have symptoms or die from the disease; most prostate cancers are slowly progressive and not life threatening.

- Screening with the PSA test may lead to a small reduction in prostate cancer mortality but not a reduction in all-cause mortality.

- Thresholds for PSA of 2.5 to $4.0 \mathrm{ng} / \mathrm{mL}$ are commonly used for screening; lower thresholds increase the probability of false-positive results, and no threshold completely excludes prostate cancer.

- Harms associated with PSA screening (e.g., bleeding, infection, urinary incontinence, a false-positive result and overdiagnosis) are common.

- The PSA test should not be used for screening without a detailed discussion with the patient, ideally with the use of decision aids to facilitate comprehension. 
available at www.cmaj.ca/lookup/suppl/doi:10 $.1503 / \mathrm{cmaj} .140703 /-/ \mathrm{DC} 1)$ that established the overall purpose and background of the guideline, framed the literature review and outlined the key and contextual research questions. The analytical framework was reviewed by all members of the task force and underwent external review by national and international stakeholders with expertise in prostate cancer before guideline development. The key and contextual questions in the analytical framework examined the benefits and harms of PSA screening with or without digital rectal examination and the benefits and harms of treatment of prostate cancer on decreasing prostate cancer mortality and all-cause mortality.

The Evidence Review and Synthesis Centre at McMaster University (Hamilton, Ont.) conducted a systematic review of the available evidence with the aid of a urologist, who served as an independent technical advisor, and scientific staff at the Public Health Agency of Canada. ${ }^{13}$ The systematic review was done according to the final, peer-reviewed protocol (http://canadiantask force.ca/perch/resources/ctfphc-prostate-cancer -screening-protocol.pdf) of the analytical framework and followed the methods described in the procedure manual..$^{14}$ Because a previous search by the US Preventive Services Task Force was used to identify data published before 2007, the timeline to review the benefits of screening was extended from Jan. 1, 2007, to Nov. 30, 2013. The search for harms data went from 2003 to
Nov. 30, 2013. The timeline for the treatment review was from Jan. 1, 2007, to Nov. 30, 2012. The search was updated Aug. 15, 2014, to include eligible trials that reported extended follow-up. Databases searched included PubMed, Ovid MEDLINE, MEDLINE, the Cochrane Central Register of Controlled Trials and the Cochrane Database of Systematic Reviews. The methods and findings of the systematic review ${ }^{13}$ can be obtained at www.canadiantaskforce.ca. The task force used the Grading of Recommendations Assessment, Development and Evaluation (GRADE) system to determine the quality of evidence and strength of recommendations (Box 1). ${ }^{15}$ The protocol, systematic review and guideline underwent external peer review by academic and clinical experts.

\section{Benefits of PSA screening}

A summary of the data described in this section can be found in Appendix 2 (available at www .cmaj.ca/lookup/suppl/doi:10.1503/cmaj.140703 /-/DC1), with detailed tables available in the systematic review. ${ }^{13}$

The literature search for the systematic review identified six randomized controlled trials (RCTs). ${ }^{16-21}$ Because three of the trials ${ }^{16-18}$ were considered to have a high risk of bias, evidence from these trials was not considered for this guideline. None of the excluded studies showed benefit from prostate cancer screening. Findings

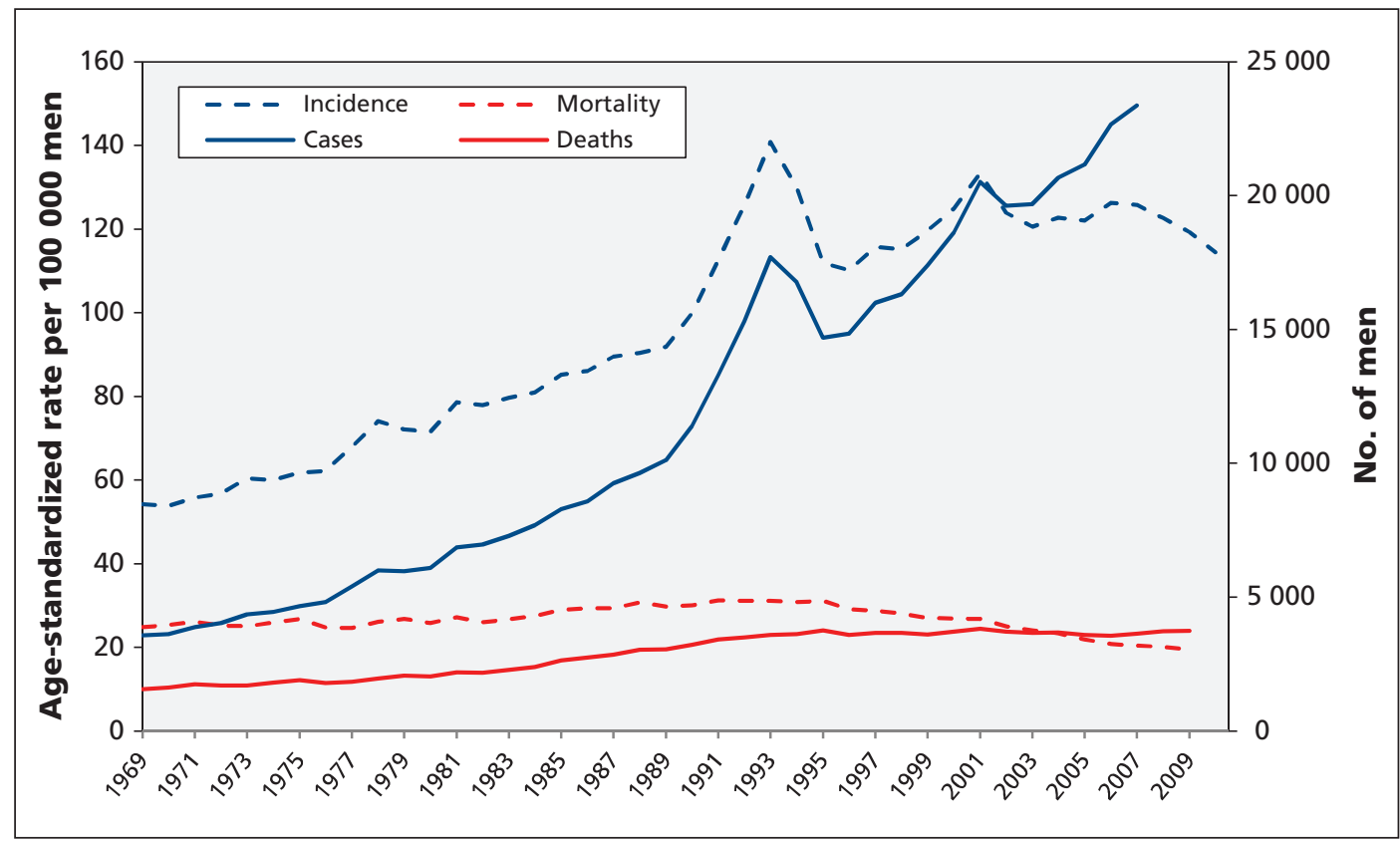

Figure 1: Cases of and deaths from prostate cancer, with associated age-standardized incidence and mortality (per 100000 men), among Canadian men aged 45 years and older. Age was standardized to the 1991 Canadian population. Incidence data were not available for Quebec from 2008 to 2010; therefore, the population denominator for age-standardized incidence was adjusted and case counts for 2008-2010 were omitted. Mortality data were available only to 2009. 
from all sites of the European Randomized Study of Screening for Prostate Cancer (ERSPC), ${ }^{19}$ a multi-country study, were considered together when we formulated the recommendations.

A small absolute reduction in prostate cancer mortality was reported in the ERSPC study. ${ }^{19}$ The investigators found that the risk of death from prostate cancer was reduced in the screening group (relative risk [RR] 0.79, 95\% confidence interval [CI] 0.69-0.91; absolute risk reduction $0.128 \%$, or 13 lives saved per 10000 men invited for screening), with a pretrial PSA testing rate of $20 \% .{ }^{13,19}$ However, there was evidence of heterogeneity between study centres, with some finding that screening reduced prostate cancer mortality while others did not.

In contrast, the Prostate, Lung, Colorectal, and Ovarian Cancer Screening Trial (PLCO) found no effect of screening on prostate cancer mortality (RR $1.09,95 \%$ CI $0.87-1.36$; 0 deaths from prostate cancer prevented per 10000 invited for screening).$^{21}$ Participants in the PLCO trial had a high rate of pretrial PSA testing (52\%), but sensitivity analysis found no effect of pretrial PSA testing on the results. High rates of opportunistic PSA screening were observed in the control group, however, which decreased the opportunity to show a beneficial effect of screening. Therefore, although the lack of benefit observed in the PLCO trial reduces confidence that PSA screening truly does reduce prostate cancer mortality, the task force placed relatively more weight on the findings of the ERSPC study.

There was no demonstrable effect of PSA screening on all-cause mortality in the PLCO or ERSPC studies (Table 1). ${ }^{13,15,19,21}$

Digital rectal examination has been traditionally used to screen for prostate cancer, but no trials have examined the mortality benefit of this screening method when used alone. ${ }^{22}$ The PLCO study used both PSA and digital rectal examination for screening of all participants. In contrast, some of the ERSPC study centres used PSA as the primary screening test, followed by digital rectal examination depending on the PSA test result; other centres used both methods for initial

\section{Box 1: Grading of recommendations}

- Recommendations are graded according to the Grading of Recommendations Assessment, Development and Evaluation (GRADE) system. ${ }^{15}$ GRADE offers two strengths of recommendation: strong and weak. The strength of recommendations is based on the quality of supporting evidence, the degree of uncertainty about the balance between desirable and undesirable effects, the degree of uncertainty or variability in values and preferences, and the degree of uncertainty about whether the intervention represents a wise use of resources.

- Strong recommendations are those for which the task force is confident that the desirable effects of an intervention outweigh its undesirable effects (strong recommendation for an intervention) or that the undesirable effects of an intervention outweigh its desirable effects (strong recommendation against an intervention). A strong recommendation implies that most individuals will be best served by the recommended course of action.

- Weak recommendations are those for which the desirable effects probably outweigh the undesirable effects (weak recommendation for an intervention) or the undesirable effects probably outweigh the desirable effects (weak recommendation against an intervention) but appreciable uncertainty exists. A weak recommendation implies that most men would want the recommended course of action but that many would not. For clinicians, this means they must recognize that different choices will be appropriate for each person, and they must help each patient arrive at a management decision consistent with his values and preferences. Policy-making will require substantial debate and involvement of various stakeholders. Weak recommendations result when the balance between desirable and undesirable effects is small, the quality of evidence is lower, or there is more variability in the values and preferences of patients.

- The quality of evidence is graded as high, moderate, low or very low, based on how likely further research is to change our confidence in the estimate of effect.

Table 1: Evidence of benefit of screening for prostate cancer with PSA testing

\begin{tabular}{|c|c|c|c|c|c|c|c|}
\hline Study (country) & Study characteristics & $\begin{array}{c}\text { PSA } \\
\text { threshold, } \\
\mathrm{ng} / \mathrm{mL}\end{array}$ & $\begin{array}{l}\text { Contamination } \\
\text { (rate of screening in } \\
\text { control group), \% }\end{array}$ & $\begin{array}{c}\text { Prostate cancer } \\
\text { mortality, } \\
\text { RR }(95 \% \mathrm{Cl})\end{array}$ & $\begin{array}{c}\text { All-cause } \\
\text { mortality, } \\
\text { RR }(95 \% \mathrm{CI})\end{array}$ & $\begin{array}{c}\text { Absolute } \\
\text { effect }\end{array}$ & $\begin{array}{l}\text { GRADE } \\
\text { quality of } \\
\text { evidence* }\end{array}$ \\
\hline $\begin{array}{l}\mathrm{PLCO}^{21} \\
\text { (United States) }\end{array}$ & $\begin{array}{l}\text { RCT; } 76693 \text { men } \\
\text { aged 55-74 yr; } \\
\text { annual PSA screening } \\
\text { for } 6 \text { yr and digital } \\
\text { rectal examination } \\
\text { annually for } 4 \text { yr; } \\
\text { 14-yr follow-up }\end{array}$ & 4 & 52 & $1.09(0.87-1.36)$ & $0.96(0.93-1.00)$ & No effect & Moderate \\
\hline $\begin{array}{l}\text { ERSPC }^{19} \\
\text { (Finland, } \\
\text { Sweden, Italy, } \\
\text { the Netherlands, } \\
\text { Belgium, Spain } \\
\text { and Switzerland) }\end{array}$ & $\begin{array}{l}\text { RCT; } 162243 \text { men } \\
\text { aged 50-74 yr (core } \\
\text { group 55-69 yr); } \\
\text { PSA screening every } \\
4 \text { yr; 13-yr follow-up }\end{array}$ & $\begin{array}{l}3.0 \text { at } \\
\text { most sites }\end{array}$ & 20 & $\begin{array}{l}\text { Core group: } \\
0.79 \text { (0.69-0.91) } \\
\text { All ages: } \\
0.83 \text { (0.73-0.94) }\end{array}$ & $\begin{array}{l}\text { Core group: } \\
1.00 \text { (0.98-1.02) } \\
\text { All ages: } \\
1.00(0.98-1.02)\end{array}$ & $\begin{array}{l}12.8 \text { fewer } \\
\text { deaths per } \\
10000 \text { men } \\
\text { screened }\end{array}$ & Moderate \\
\hline
\end{tabular}

Note: $\mathrm{Cl}$ = confidence interval, ERSPC = European Randomized Study of Screening for Prostate Cancer, PLCO = Prostate, Lung, Colorectal, and Ovarian Cancer

Screening Trial, PSA = prostate-specific antigen, $\mathrm{RCT}=$ randomized controlled trial, $\mathrm{RR}=$ relative risk.

${ }^{*}$ GRADE (Grading of Recommendations, Assessment, Development and Evaluation) ${ }^{15}$ rates the continuum of quality of evidence in 4 categories of high, moderate, low or very low; see evidence review for complete assessment of study quality. ${ }^{13}$ 
screening but stopped using digital rectal examination in later screening rounds. The systematic review for the current guideline found no evidence that digital rectal examination reduces mortality when used in conjunction with the PSA test. ${ }^{13}$

\section{Harms of screening}

The harms of PSA screening relate to the investigation and treatment of prostate cancer in men with true- and false-positive test results and in men whose detected prostate cancer would not have caused them symptoms or death (i.e., overdiagnosis) (Table 2)..$^{13,15,19,21}$

\section{False-positive results}

The rate of false-positive results varies depending on the PSA test threshold, ranging from $11.3 \%$ of all screened men at a threshold of $4.0 \mathrm{ng} / \mathrm{mL}$ to $19.8 \%$ at a threshold of $3.0 \mathrm{ng} / \mathrm{mL} .^{23,24}$ The PLCO study used a threshold of $4.0 \mathrm{ng} / \mathrm{mL}$ (annual screening), and most sites in the ERSPC study used a threshold of $3.0 \mathrm{ng} / \mathrm{mL}$ (screening every $4 \mathrm{yr}$ ). Lower thresholds can increase the number of cases of cancer detected, but they also increase the risk of a false-positive result and diagnosis of indolent tumours of no clinical significance. No level of PSA excludes prostate cancer. ${ }^{25,26}$ Other factors that increase the risk of a false-positive PSA test result include urinary tract infection and benign prostatic hypertrophy.

\section{Harms of biopsy}

Men who have a positive PSA test result are typically invited for further testing, which usually includes prostate biopsy. Depending on the chosen strategy for the PSA test threshold and the frequency of testing, men who undergo PSA screening could potentially have multiple biopsies over time, thereby increasing their risk of harms.

Harms of prostate biopsy include hematuria, infection, hospital admission and death. Observational studies showed that an estimated $31 \%$ of men (310 men per 1000) had hematuria up to 30 days after biopsy and that $0.9 \%$ of men ( 9 per 1000) had infection. ${ }^{13}$ A meta-analysis found that the more serious complications of hospital admission occurred in 21 men per $1000(2.1 \%$, 95\% CI $1.6 \%-2.5 \%$ ) and death in 2 per 1000 $(0.2 \%, 95 \%$ CI $0.1 \%-0.2 \%)$ (Table 2$).{ }^{13}$

\section{Overdiagnosis}

Overdiagnosis occurs when cancer is detected correctly but would not cause symptoms or death. Estimates of the frequency of overdiagnosis can be influenced by the PSA test threshold used, the frequency of screening, the patient's age, the PSA volume, the disease risk and the number of core samples taken during biopsy. Estimates can also vary depending on how they are calculated (i.e., whether the denominator is the number of patients screened, the number with a positive PSA test result or the number with a diagnosis of prostate cancer). In the ERSPC trial, the esti-

Table 2: Evidence of harms from screening for prostate cancer with PSA testing*

\begin{tabular}{|c|c|c|c|c|}
\hline Harm & Study type & Study characteristics & Proportion $(95 \% \mathrm{Cl})$ & $\begin{array}{l}\text { GRADE quality } \\
\text { of evidencet }\end{array}$ \\
\hline Overdiagnosis $¥$ & $\begin{array}{l}\text { ERSPC modelling data; }{ }^{19} \\
\text { various sources }\end{array}$ & & $40 \%-56 \%$ of cases diagnosed & Very low \\
\hline \multirow[t]{2}{*}{$\begin{array}{l}\text { False-positive } \\
\text { result }\end{array}$} & $\begin{array}{l}\text { ERSPC; }{ }^{19} \text { uncontrolled } \\
\text { observational study }\end{array}$ & $\begin{array}{l}\mathrm{PSA}>3.0 \mathrm{ng} / \mathrm{mL} \text { as } \\
\text { threshold for biopsy } \\
\text { referral }\end{array}$ & $19.82 \%(11.51 \%-28.13 \%)$ of men screened & Very low \\
\hline & $\begin{array}{l}\text { ERSPC }{ }^{19} \text { and intervention } \\
\text { arm of PLCO; }{ }^{21} \text { uncontrolled } \\
\text { observational study }\end{array}$ & $\begin{array}{l}\mathrm{PSA}>4.0 \mathrm{ng} / \mathrm{mL} \text { as } \\
\text { threshold for biopsy } \\
\text { referral }\end{array}$ & $11.30 \%(9.92 \%-12.67 \%)$ of men screened & Very low \\
\hline \multirow[t]{3}{*}{ Harms of biopsy } & \multirow[t]{3}{*}{$\begin{array}{l}\text { Uncontrolled observational } \\
\text { study }\end{array}$} & \multirow[t]{3}{*}{$<30 \mathrm{~d}$ after biopsy } & $\begin{array}{l}\text { Hematuria§ = mean } 30.86 \%(20.18 \%-41.51 \%) \\
\text { of men who had a biopsy } \\
\text { Infection } \S=\text { mean } 0.94 \%(0.01 \%-1.86 \%) \text { of } \\
\text { men who had a biopsy }\end{array}$ & Very low \\
\hline & & & $\begin{array}{l}\text { Hospital admission }=\text { mean } 2.07 \% \\
(1.59 \%-2.54 \%) \text { of men who had a biopsy }\end{array}$ & Very low \\
\hline & & & $\begin{array}{l}\text { Death }=\text { mean } 0.17 \%(0.09 \%-0.25 \%) \text { of men } \\
\text { who had a biopsy }\end{array}$ & Very Low \\
\hline \multicolumn{5}{|c|}{$\begin{array}{l}\text { Note: } \mathrm{Cl}=\text { confidence interval, ERSPC = European Randomized Study of Screening for Prostate Cancer, PLCO = Prostate, Lung, Colorectal, and Ovarian Cancer } \\
\text { Screening Trial, PSA = prostate-specific antigen. } \\
\text { *All data can be found in Dunfield et al. } \\
\text { †GRADE (Grading of Recommendations, Assessment, Development and Evaluation) }{ }^{15} \text { rates the continuum of quality of evidence in } 4 \text { categories of high, } \\
\text { moderate, low or very low; see evidence review for complete assessment of study quality. }{ }^{13} \\
\text { ‡Overdiagnosis = the detection of cancers that would not progress to cause symptoms or death. } \\
\text { §Not requiring hospital admission. }\end{array}$} \\
\hline
\end{tabular}


mated prevalence of overdiagnosis ranged from $40 \%$ to $56 \%$ of men screened who received a diagnosis of prostate cancer. ${ }^{13}$

\section{Benefits and harms of treatment}

Two RCTs ${ }^{27,28}$ showed that radical prostatectomy reduced prostate cancer mortality among men with symptomatic early prostate cancer. Cohort studies reported decreased prostate cancer mortality ${ }^{29-34}$ and all-cause mortality ${ }^{29-36}$ associated with radical prostatectomy. There was no trial evidence to indicate that radiation therapy improves clinical outcomes in men with prostate cancer, although pooled analyses of observational data suggested that radiation therapy (alone or in combination with hormonal therapy) reduces prostate cancer mortality and all-cause mortality. ${ }^{30-37}$ No studies showed that hormonal therapy decreased all-cause or prostate cancer mortality, and no studies of the effect of cryotherapy or high-intensity focal ultrasonography on all-cause or prostate cancer mortality were identified. ${ }^{13}$

Radical prostatectomy, radiation therapy and androgen deprivation therapy are the most common treatments of prostate cancer and are associated with potential harms. In RCTs that compared radical prostatectomy with watchful waiting, men in both study arms had the potential to receive other treatments, which made it difficult to estimate the harms from a specific treatment. After 12.4 years of follow-up in the Scandinavian Prostate Cancer Group (SPCG-4) study, the cumulative prevalence of erectile dysfunction was $84 \%$ in the intervention group and $80 \%$ in the watchful-waiting group; the rates of urinary leakage were $41 \%$ and $11 \%$, respectively. ${ }^{38}$ After 2 years of follow-up in the Prostate Cancer Intervention Versus Observation Trial (PIVOT), men who underwent radical prostatectomy had higher rates of urinary incontinence $(17.1 \%$ v. $6.3 \%)$ and erectile dysfunction $(81.1 \%$ v. $44.1 \%)$ than men in the observation arm. ${ }^{28}$ Cohort studies consistently reported an increased risk of erectile dysfunction associated with radical prostatectomy (RR 1.6, 95\% CI 1.31.8 , affecting $23.4 \%$ or 234 per 1000 of men) compared with no treatment. ${ }^{39-43}$ Both RCTs ${ }^{28,38}$ and cohort studies ${ }^{39-42}$ found that radical prostatectomy increased the risk of urinary incontinence compared with watchful waiting (metaanalysis of trial data: RR 3.2, 95\% CI 2.3-4.6; $17.8 \%$ of men or 178 per 1000 affected $^{13}$ ).

In addition, between $11 \%$ and $21 \%$ of men will experience short-term $(<30 \mathrm{~d})$ postoperative complications, such as infection, additional surgery and blood transfusions. ${ }^{28,44-46}$ Trial data in- dicate that radiation therapy increases the risk of urinary incontinence ${ }^{47}$ (not supported by observational studies ${ }^{13}$ ) and erectile dysfunction..$^{39-42}$ Combined radiation and hormonal therapy also increases the risk of bowel and erectile dysfunction. ${ }^{13}$ Hormonal therapy (androgen deprivation therapy) has been shown to increase the risk of erectile dysfunction $(76 \%$ v. $33 \%$ in control group), but not urinary incontinence (9\% v. $6 \%$ in control group). ${ }^{13}$

The studies included in the systematic review used various strategies for following control participants that often were not clearly defined. ${ }^{13}$ It was unclear which (if any) control groups were followed with active surveillance (continued monitoring with repeat PSA testing, and biopsy and treatment depending on the test results ${ }^{48}$ ) or with watchful waiting (no active treatment; treatment of symptoms only as they progress ${ }^{48}$ ).

\section{Recommendations}

A summary of the recommendations is shown in Box 2, and a clinical summary is provided in Appendix 3 (www.cmaj.ca/lookup/suppl/doi :10.1503/cmaj.140703/-/DC1). The task force based the recommendations on the overall balance between the possible benefits and harms of PSA screening (with or without digital rectal examination), weighing the possible benefits against potential harms of early diagnosis and treatment of prostate cancer. There is (a) no evidence that PSA screening reduces overall mortality among men of any age; (b) conflicting evidence suggesting a small and uncertain potential reduction in prostate cancer mortality among men aged 55-69 years; (c) no convincing evidence of a reduction in prostate cancer mortality in any other age group; and (d) consistent evidence that screening and active treatment lead to harm.

Box 2: Summary of recommendations for clinicians and policy-makers

The recommendations apply to all men without a previous diagnosis of prostate cancer.

- For men aged less than 55 years, we recommend not screening for prostate cancer with the prostate-specific antigen (PSA) test. (Strong recommendation; low-quality evidence.)

- For men aged 55-69 years, we recommend not screening for prostate cancer with the PSA test. (Weak recommendation; moderate-quality evidence.)

- For men 70 years of age and older, we recommend not screening for prostate cancer with the PSA test. (Strong recommendation; low-quality evidence.) 
Recommendations apply to men in the general population. This includes men with lower urinary tract symptoms (e.g., nocturia, urgency, frequency and poor stream) and those with benign prostatic hyperplasia. About $25 \%$ of men in the screening trials had lower urinary tract symptoms, and benign prostatic hyperplasia is not a risk factor for prostate cancer. ${ }^{49}$

Groups at increased risk of prostate cancer and of dying from it include men of black race and men with a family history of prostate cancer. There are no trial data showing that the benefits or harms of screening differ in these populations, as compared with men in the general population. However, clinicians may wish to discuss the benefits and harms of screening with men at increased risk of prostate cancer, with explicit consideration of their values and preferences.

Recommendations do not apply to the use of the PSA test for surveillance after diagnosis or treatment of prostate cancer.

\section{Men aged less than $\mathbf{5 5}$ years}

For men aged less than 55 years of age, we recommend not screening for prostate cancer with the PSA test. (Strong recommendation; low-quality evidence.)

This recommendation is based on the low incidence of prostate cancer and prostate cancer mortality, and the lack of evidence for benefit of screening in this age group, as well as the evidence of harms.

\section{Men aged 55-69 years}

For men aged 55-69 years of age, we recommend not screening for prostate cancer with the PSA test. (Weak recommendation; moderate-quality evidence.)

This recommendation places a relatively low value on a small and uncertain potential reduction in prostate cancer mortality, and a relatively higher value on the risk of a false-positive result, unnecessary biopsies, overdiagnosis of prostate cancer and harms associated with unnecessary treatment. The risks and benefits of PSA screening and its potential consequences should be discussed with each patient in the context of his preferences. Men who place a high value on a small potential reduction in mortality and are less concerned with undesirable consequences may choose to be screened.

\section{Men $\mathbf{7 0}$ years of age and older}

For men 70 years of age and older, we recommend not screening for prostate cancer with the PSA test. (Strong recommendation; low-quality evidence.)

This recommendation reflects the lower life expectancy and the lack of evidence for benefit of screening in this age group as well as the evidence of harms.

For men aged less than 55 years and those 70 years and older, the strong recommendations against PSA screening reflect our certainty that the potential harms of screening outweigh the benefits given the current state of knowledge.

\section{Considerations for implementation}

\section{Patient values and preferences}

Because of recent efforts to encourage screening for prostate cancer, some men may be interested in PSA screening despite the current recommendations. Evidence suggests that a patient's perceived vulnerability to the disease, as a result of family history or otherwise, and physician recommendation are both associated with patient request for screening with the PSA test. ${ }^{50}$ Although high-quality evidence on the best way to facilitate informed decision-making about prostate cancer screening is lacking, such discussions should aim to elicit the knowledge, preferences and values of patients who ask about PSA screening. ${ }^{51,52}$ Many men view screening positively but are unaware of the potential harms..$^{53}$ In addition to a focus on the patient's values and preferences, informed decision-making requires practitioners to distinguish between the benefits and harms of screening, subsequent investigations and treatment, including an overview of diagnostic and therapeutic options in the event that the PSA test result is abnormal.

The task force recognizes that some men may place greater value on the potential benefits of screening than on the harms and risks associated with diagnosis and treatment and may choose to be screened with the PSA test. To facilitate informed decision-making about screening for prostate cancer, the task force has developed decision aids and tools that are available at www.canadiantaskforce.ca.

\section{Costs}

The task force did not consider the costs of screening or treatment of prostate cancer when formulating these recommendations.

\section{Suggested performance indicators}

Suggested performance measures include rates of PSA testing and subsequent follow-up, and the degree to which men who request screening were accurately informed of the risks and benefits of screening (ideally using an evidence-based decision aid). Incidence and mortality data related to prostate cancer should continue to be monitored at the provincial, territorial and national levels. 


\section{Other guidelines}

The screening recommendations from other national and international organizations are shown in Table 3. ${ }^{8,11,22,54-61}$ The current recommendations are consistent with the task force's 1994 recommendations and with the latest guidelines from the US Preventive Services Task Force ${ }^{8}$ and Cancer Council Australia. ${ }^{61}$ The National Health Service in the United Kingdom has no organized screening program, but it suggests that men who are concerned about the risk of prostate cancer receive clear and balanced information about the advantages and disadvantages of the PSA test and prostate cancer treatments. ${ }^{57}$

\section{Other screening tests}

Several tests to supplement the PSA test in screening for prostate cancer have been developed in recent years. These tests are intended to detect cell activity in potentially malignant cells

Table 3: Summary of recommendations for PSA screening for prostate cancer from Canada and elsewhere

\begin{tabular}{|c|c|c|c|}
\hline Organization & Age at initiation of PSA screening & Screening interval & $\begin{array}{l}\text { Age at discontinuation } \\
\text { of PSA screening }\end{array}$ \\
\hline $\begin{array}{l}\text { Canadian Task Force on } \\
\text { Preventive Health Care } \\
\text { (current) }\end{array}$ & \multicolumn{3}{|l|}{ Routine PSA screening not recommended } \\
\hline $\begin{array}{l}\text { Canadian Task Force on the } \\
\text { Periodic Health } \\
\text { Examination (1994) })^{11}\end{array}$ & \multicolumn{3}{|c|}{ Routine PSA screening not recommended as part of periodic health examination } \\
\hline $\begin{array}{l}\text { US Preventive Services Task } \\
\text { Force }(2012)^{8}\end{array}$ & \multicolumn{3}{|c|}{ PSA screening not recommended; applies to men of all ages } \\
\hline $\begin{array}{l}\text { Canadian Urological } \\
\text { Association }(2011)^{54}\end{array}$ & $\begin{array}{l}\text { - Average risk: offer at age } 50 \mathrm{yr} \text { to men } \\
\text { with life expectancy } \geq 10 \mathrm{yr} \\
\text { - Increased risk (e.g., family history of prostate } \\
\text { cancer, African descent): offer at } 40 \mathrm{yr} \\
\text { - Offer baseline PSA test at age } 40-49 \mathrm{yr} \text { to } \\
\text { establish future risk of prostate cancer }\end{array}$ & Not specified & $75 \mathrm{yr}$ \\
\hline $\begin{array}{l}\text { Canadian Cancer Society } \\
(2014)^{55}\end{array}$ & $\begin{array}{l}\text { Men aged }>50 \text { yr should talk with their } \\
\text { doctor about whether they should be tested } \\
\text { for prostate cancer }\end{array}$ & Not specified & Not specified \\
\hline $\begin{array}{l}\text { American Cancer Society } \\
(2012)^{56}\end{array}$ & $\begin{array}{l}\text { Average risk: discussion at age } 50 \mathrm{yr} \\
\text { Increased risk: discussion at age } 40 \text { or } 45 \mathrm{yr} \text {, } \\
\text { depending on extent of risk }\end{array}$ & $\begin{array}{l}\text { PSA }<2.5 \mathrm{ng} / \mathrm{mL}: 2 \mathrm{yr} \\
\text { PSA } \geq 2.5 \mathrm{ng} / \mathrm{mL}: \text { annual }\end{array}$ & $\begin{array}{l}\text { Life expectancy } \\
\qquad<10 \mathrm{yr}\end{array}$ \\
\hline $\begin{array}{l}\text { National Cancer Institute } \\
(2012)^{22}\end{array}$ & \multicolumn{3}{|c|}{$\begin{array}{l}\text { Insufficient evidence to determine whether screening with PSA or digital rectal examination } \\
\text { reduces prostate cancer mortality }\end{array}$} \\
\hline $\begin{array}{l}\text { National Health Service } \\
(2013)^{57}\end{array}$ & \multicolumn{3}{|c|}{$\begin{array}{l}\text { No organized screening program; informed-choice program }=\text { men concerned about the risk of } \\
\text { prostate cancer receive clear and balanced information about the advantages and disadvantages } \\
\text { of PSA testing and cancer treatment }\end{array}$} \\
\hline $\begin{array}{l}\text { Prostate Cancer Canada } \\
(2013)^{58}\end{array}$ & $\begin{array}{l}\text { - Offer baseline PSA test at age } 40-49 \mathrm{yr} \\
\text { - Men aged }>40 \text { yr should talk with their } \\
\text { doctor about early detection } \\
\text { - Men at high risk should talk with their } \\
\text { primary care provider before age } 40 \mathrm{yr} \\
\text { about prostate cancer }\end{array}$ & Not specified & $\begin{array}{l}\geq 70 \mathrm{yr} \text {; decision } \\
\text { should be based on } \\
\text { individual factors } \\
\text { (not specified) }\end{array}$ \\
\hline $\begin{array}{l}\text { American Urological } \\
\text { Association }(2013)^{59}\end{array}$ & $\begin{array}{l}\text { - Routine screening not recommended for } \\
\text { men aged } 40-54 \text { yr at average risk } \\
\text { - Shared decision-making recommended for } \\
\text { men aged 55-69 yr; decision to proceed } \\
\text { based on patient's values and preferences }\end{array}$ & $\geq 2 \mathrm{yr}$ & $\begin{array}{l}\geq 70 \mathrm{yr} \text { or } \\
\text { life expectancy } \\
\quad<10-15 \mathrm{yr}\end{array}$ \\
\hline $\begin{array}{l}\text { American College of } \\
\text { Physicians }(2013)^{60}\end{array}$ & $\begin{array}{l}\text { Men aged 50-69 yr: clinicians should discuss } \\
\text { the limited benefits and substantial harms of } \\
\text { screening for prostate cancer; they should } \\
\text { not screen for prostate cancer with the PSA } \\
\text { test in patients who do not express a clear } \\
\text { preference for screening }\end{array}$ & Not specified & $\begin{array}{l}\quad \geq 70 \mathrm{yr} \text { or } \\
\text { life expectancy } \\
\quad<10-15 \mathrm{yr}\end{array}$ \\
\hline $\begin{array}{l}\text { Cancer Council Australia, } \\
\text { Australian Health Ministers' } \\
\text { Advisory Council (2010) }\end{array}$ & $\begin{array}{l}\text { PSA test not suitable for population } \\
\text { screening }\end{array}$ & & \\
\hline
\end{tabular}


and are aimed at assessing risk during various stages, such as after a positive biopsy result, ${ }^{62}$ after a negative biopsy result ${ }^{63-65}$ and after surgery. ${ }^{66}$ These tests measure molecular markers, which typically indicate patterns of gene activity, such as expression of the PCA3 gene and other DNA mutations, which occur in the presence of a malignant tumour. We recommend that such tests not be used until sufficient evidence is available on their diagnostic performance, harms and benefits.

\section{Gaps in knowledge}

Future research may be best focused on finding alternatives to the PSA test for prostate cancer screening and reducing inappropriate PSA testing. It has been suggested that baseline PSA testing could help to assess the future risk of death or metastasis from prostate cancer (which could support risk-based screening ${ }^{67,68}$ ), but more work is needed before this approach could be recommended. Magnetic resonance imaging and clinical decision rules are also promising approaches to improving the risk:benefit ratio of screening, but they have not been tested in rigorous randomized trials. Future research should also develop methods to identify the subset of men with prostate cancer in whom clinically relevant disease would develop (in the absence of treatment). Altering PSA thresholds or screening intervals, as well as uncoupling screening from treatment (because some men may opt for watchful waiting or active surveillance instead of active treatment), may favourably change the risk:benefit ratio of PSA screening; however, more research is needed to test this hypothesis. Trials investigating the benefits of PSA screening among men with a family history of prostate cancer or men of black race would be helpful to determine whether screening in these high-risk populations is warranted. Finally, randomized trials should compare watchful waiting or active surveillance, or both, with treatment with a curative intent.

\section{Conclusion}

Available evidence does not conclusively show that PSA screening will reduce prostate cancer mortality, but it clearly shows an increased risk of harm. The task force recommends that the PSA test should not be used to screen for prostate cancer. The implication of the strong recommendations against screening men less than 55 years of age and those 70 years of age and older is that clinicians should not routinely discuss screening with men in these age groups un- less the topic is raised by the patient. The implication of the weak recommendation against screening men aged 55-69 years is that clinicians who believe a patient places a high value on the small potential benefit of screening and is less concerned about the harms may wish to discuss the benefits and harms of screening with the patient so that he can make an informed decision about whether to be screened. Any use of PSA testing to screen for prostate cancer requires a thoughtful discussion between the clinician and the patient about the balance between unclear benefits and substantial harms.

\section{References}

1. Canadian Cancer Society Advisory Committee on Cancer Statistics. Canadian cancer statistics 2013. Toronto: Canadian Cancer Society; 2013. ISSN 0835-2976.

2. Canadian cancer statistics 2011 [Table 6.1]. Toronto: Canadian Cancer Society; 2011. Available: www.cancer.ca/ /media /cancer.ca/CW/cancer\%20information/cancer\%20101/Canadian $\% 20$ cancer\%20statistics/Canadian-Cancer-Statistics-2011-EN .pdf (accessed 2014 Sept. 22).

3. Powell IJ, Bock CH, Ruterbusch JJ, et al. Evidence supports a faster growth rate and/or earlier transformation to clinically significant prostate cancer in black than in white american men, and influences racial progression and mortality disparity. J Urol 2010;183:1792-6.

4. Etzioni R, Penson DF, Legler JM, et al. Overdiagnosis due to prostate-specific antigen screening: lessons from the US prostate cancer incidence trends. J Natl Cancer Inst 2002;94:981-90.

5. Bangma CH, Roemeling S, Schroder FH. Overdiagnosis and overtreatment of early detected prostate cancer. World J Urol 2007;25:3-9.

6. Brawley OW. Prostate cancer screening: What we know, don't know, and believe. Ann Intern Med 2012;157:135-6.

7. Schröder FH, Roobol MJ. Prostate cancer epidemic in sight? Eur Urol 2012;61:1093-5.

8. Moyer VA; US Preventive Services Task Force. Screening for prostate cancer: US Preventive Services Task Force recommendation statement. Ann Intern Med 2012;157:120-34.

9. Perron L, Moore L, Bairati I, et al. PSA screening and prostate cancer mortality. CMAJ 2002;166:586-91.

10. Center MM, Jemal A, Lortet-Tierulent J, et al. International variation in prostate cancer incidence and mortality rates. Eur Urol 2012;61:1079-92.

11. Canadian Task Force on the Periodic Health Examination. Screening for prostate cancer. In: The Canadian guide to clinical preventive health care. Ottawa: Canada Communication Group; 1994:812.

12. Connor Gorber S, Singh H, Pottie K, et al. Process for guideline development by the reconstituted Canadian Task Force on Preventive Health Care. CMAJ. 2012;184:1575-81

13. Dunfield L, Usman A, Fitzpatrick-Lewis D, et al., editors. Screening for prostate cancer with prostate specific antigen (PSA) and treatment of early-stage or screen-detected prostate cancer: a systematic review of the clinical benefits and harms. Ottawa: Canadian Task Force on Preventive Health Care; 2013.

14. The Canadian Task Force on Preventive Health procedure manual. Ottawa: Canadian Task Force on Preventive Health Care; 2014.

15. Schünemann H, Brozek J, Oxman A. GRADE handbook for grading quality of evidence and strength of recommendations. Version 3.2 [updated March 2009]. GRADE Working Group; 2009.

16. Kjellman A, Akre O, Norming U, et al. 15-year followup of a population based prostate cancer screening study. J Urol 2009; 181:1615-21

17. Sandblom G, Varenhorst E, Rosell J, et al. Randomised prostate cancer screening trial: 20 year follow-up. BMJ 2011;342:d1539.

18. Labrie F, Candas B, Cusan L, et al. Screening decreases prostate cancer mortality: 11-year follow-up of the 1988 quebec prospetive randomized controlled trial. Prostate 2004;59:311-8.

19. Schröder FH, Hugosson J, Roobol MJ, et al. Screening and prostate cancer mortality: results of the European Randomised Study of Screening for Prostate Cancer (ERSPC) at 13 years of followup. Lancet 2014; Aug. 6 [Epub ahead of print]. 
20. Hugosson J, Carlsson S, Aus G, et al. Mortality results from the Göteborg randomised population-based prostate-cancer screening trial. Lancet Oncol 2010;11:725-32.

21. Andriole GL, Crawford ED, Grubb RL III, et al. Prostate cancer screening in the randomized Prostate, Lung, Colorectal and Ovarian cancer screening trial: mortality results after 13 years of follow-up. J Natl Cancer Inst 2012;104:125-32.

22. Prostate cancer screening (PDQ $\left.{ }^{\circledR}\right)$. Bethesda (MD): National Cancer Institute; 2014. Available: www.cancer.gov/cancertopics /pdq/screening/prostate/HealthProfessional/page1 (accessed 2014 Sept. 9).

23. Croswell JM, Kramer BS, Kreimer AR, et al. Cumulative incidence of false-positive results in repeated, multimodal cancer screening. Ann Fam Med 2009; 7:212-22.

24. Kilpelainen TP, Tammela TL, Roobol M, et al. False-positive screening results in the European Randomized Study of Screening for Prostate Cancer. Eur J Cancer 2011;47:2698-705.

25. Thompson IM, Pauler DK, Goodman PJ, et al. Prevalence of prostate cancer among men with a prosate-specific antigen level $<$ or $=4.0 \mathrm{ng}$ per milliliter. $N$ Engl J Med 2004;350:2239-46.

26. Thompson IM, Goodman PJ, Tangen CM, et al. The influence of finasteride on the development of prostate cancer. $N$ Engl J Med 2003;349:215-24.

27. Bill-Axelson A, Holmberg L, Ruutu M, et al. Radical prostatectomy versus watchful waiting in early prostate cancer. $N$ Engl J Med 2011; 364:1708-17.

28. Wilt TJ, Brawer MK, Jones KM, et al. Radical prostatectomy versus observation for localized prostate cancer. $N$ Engl J Med 2012; 367:203-13.

29. Abdollah F, Sun M, Schmitges J, et al. Cancer-specific and other-cause mortality after radical prostatectomy versus observation in patients with prostate cancer: competing-risks analysis of a large north American population-based cohort. Eur Urol 2011;60:920-30.

30. Albertsen PC, Hanley JA, Penson DF, et al. 13-year outcomes following treatment for clinically localized prostate cancer in a population based cohort. J Urol 2007;177:932-6.

31. Merglen A, Schmidlin F, Fioretta G, et al. Short- and long-term mortality with localized prostate cancer. Arch Intern Med 2007; 167:1944-50.

32. Stattin P, Holmberg E, Johansson JE, et al. Outcomes in localized prostate cancer: National Prostate Cancer Register of Sweden follow-up study. J Natl Cancer Inst 2010;102:950-58

33. Tewari A, Divine G, Chang P, et al. Long-term survival in men with high grade prostate cancer: a comparison between conservative treatment, radiation therapy and radical prostatectomy a propensity scoring approach. J Urol 2007;177:911-5.

34. Zhou EH, Ellis RJ, Cherullo E, et al. Radiotherapy and survival in prostate cancer patients: a population-based study. Int J Radiat Oncol Biol Phys 2009;73:15-23.

35. Wong YN, Mitra N, Hudes G, et al. Survival associated with treatment vs observation of localized prostate cancer in elderly men. JAMA 2006;296:2683-93.

36. Schymura MJ, Kahn AR, German RR, et al. Factors associated with initial treatment and survival for clinically localized prostate cancer: results from the CDC-NPCR Patterns of Care Study (PoC1). BMC Cancer 2010;10:152.

37. Abdollah F, Sun M, Schmitges J, et al. Competing-risks mortality after radiotherapy vs. observation for localized prostate cancer: a population-based study. Int J Radiat Oncol Biol Phys 2012;84: 95-103.

38. Johansson E, Steineck G, Holmberg L, et al. Long-term qualityof-life outcomes after radical prostatectomy or watchful waiting: the Scandinavian Prostate Cancer Group-4 randomised trial. Lancet Oncol 2011;12:891-9.

39. Hoffman RM, Hunt WC, Gilliland FD, et al. Patient satisfaction with treatment decisions for clinically localized prostate carcinoma: results from the prostate cancer outcomes study. Cancer 2003;97:1653-62.

40. Litwin MS. Health-related quality of life after treatment for localized prostate cancer. Cancer 1995;75:2000-3.

41. Schapira MM, Lawrence WF, Katz DA, et al. Effect of treatment on quality of life among men with clinically localized prostate cancer. Med Care 2001;39:243-53.

42. Smith DP, King MT, Egger S, et al. Quality of life three years after diagnosis of localised prostate cancer: population based cohort study. BMJ 2009;339:b4817.

43. Siegel T, Moul JW, Spevak M, et al. The development of erectile dysfunction in men treated for prostate cancer. J Urol 2001; 165:430-5.

44. Alibhai SM, Leach M, Tomlinson G, et al. 30-day mortality and major complications after radical prostatectomy: influence of age and comorbidity. J Natl Cancer Inst 2005;97:1525-32.

45. Augustin H, Hammerer P, Graefen M, et al. Intraoperative and perioperative morbidity of contemporary radical retropubic prostatectomy in a consecutive series of 1243 patients: results of a single center between 1999 and 2002. Eur Urol 2003; 43:113-8.

46. Rabbani F, Yunis LH, Pinochet R, et al. Comprehensive standardized report of complications of retropubic and laparoscopic radical prostatectomy. Eur Urol 2010; 57:371-86.

47. Fransson P, Damber JE, Tomic R, et al. Quality of life and symptoms in a randomized trial of radiotherapy versus deferred treatment of localized prostate carcinoma. Cancer 2001;92:3111-9.

48. Active surveillance. Toronto: Prostate Cancer Canada. Available: http://prostatecancer.ca/Prostate-Cancer/Treatment/Active -Surveillance\#.Uysm3qhdV8E; 2013 (accessed 2014 Sept. 9).

49. Risk factors for prostate cancer. Toronto: Canadian Cancer Society. Available: www.cancer.ca/en/cancer-information/cancer-type /prostate/risks/?region=on;2013 (accessed 2014 Sept. 9).

50. Vedel I, Puts MTE, Monette M, et al. The decision-making proces in prostate cancer screening in primary care with a prostate-specific antigen: a systematic review. J Geriatr Oncol 2011;2:161-76.

51. Mulley AG, Trimble C, Elwyn G. Stop the silent misdiagnosis: patients' preferences matter. BMJ 2012;345:e6572.

52. Welch HG, Black WC. Overdiagnosis in cancer. J Natl Cancer Inst 2010; 102:605-13.

53. Smith SD, Birtwhistle R. Exploring patient perceptions of PSA screening for prostate cancer: risks, effectiveness, and importance. Can Fam Physician 2012;58:e502-7.

54. Izawa JI, Klotz L, Siemens DR, et al. Prostate cancer screening: Canadian guidelines 2011. Can Urol Assoc J 2011;5:235.

55. Prostate-specific antigen (PSA) test. Toronto: Canadian Cancer Society; 2014. Available: www.cancer.ca/en/cancer-information /diagnosis-and-treatment/tests-and-procedures/prostate-specific -antigen-psa/?region=on (accessed 2014 Sept. 9).

56. American Cancer Society recommendations for prostate cancer early detection. Atlanta: American Cancer Society; 2012. Available: www.cancer.org/cancer/prostatecancer/moreinformation /prostatecancerearlydetection/prostate-cancer-early-detection-acs -recommendations (accessed 2012 Nov. 1).

57. Prostate Cancer Risk Management Programme. London (UK): National Health Service; 2013. Available: www.cancerscreening .nhs.uk/prostate/index.html (accessed 2014 Sept. 9).

58. Prostate Cancer Canada — PSA recommendation: know your number. Toronto: Prostate Cancer Canada; 2013. Available: http://prostatecancer.ca/getmedia/f99f7d19-2f3a-44ad-9af9-dc44 73b2dc21/PCC-PSA-Position-2014-final-v2_1.pdf.aspx (accessed 2014 Sept. 9).

59. Ballentine Carter H, Albertsen PC, Barry MJ, et al. Early detec tion of prostate cancer: AUA guideline. Linthicum (MD): American Urological Association; 2013. Available: www.auanet .org/common/pdf/education/clinical-guidance/Prostate-Cancer -Detection.pdf (accessed 2014 Sept. 9).

60. Qaseem A, Barry MJ, Denberg TD, et al.; Clinical Guidelines Committee of the American College of Physicians. Screening for prostate cancer: a guidance statement from the Clinical Guidelines Committee of the American College of Physicians. Ann Intern Med 2013;158:761-9.

61. Position statement. Prostate cancer screening in Australia: joint key messages. Sydney (Australia): Cancer Council Australia; 2010. Available: www.cancer.org.au/content/pdf/CancerControl Policy/PositionStatements/PS-Prostate Cancer_Screening Joint _key_messages_\%20published_May2010.pdf (accessed 2014 Sept. 9).

62. Cain C. Prostate's PTEN diagnosis. SciBX 2011;4(9).

63. Ramos CG, Valdevenito R, Vergara I, et al. PCA3 sensitivity and specificity for prostate cancer detection in patients with abnormal PSA and/or suspicious digital rectal examination: first Latin American experience. Urol Oncol 2013;31:1522-6.

64. Mitomics launches flagship product - Prostate Core Mitomic Test $^{\mathrm{TM}}$ [press release]. Mitomics Inc.; 2011 Mar. 31. Available: www.mitomicsinc.com/media-center/press-detail.php?id=8 (accessed 2014 Sept. 9).

65. MDxHealth announces results from the ConfirmMDx(TM) for prostate cancer test studies presented at the 2013 ASCO Genitourinary Cancers Symposium [press release]. MDxHealth; 2013 Feb. 18. Available: www.mdxhealth.com/news-and-events/press -releases-and-events?detail=1678617 (accessed 2014 Sept. 9).

66. Moula JW, Liljab H, Semmese OJ, et al. NADiA ProsVue prostate-specific antigen slope is an independent prognostic marker for identifying men at reduced risk of clinical recurrent of prostate cancer after radical prostatectomy. Urology 2012; 80:1319-25.

67. Lilja H, Cronin AM, Dahlin A, et al. Prediction of significant prostate cancer diagnosed 20 to 30 years later with a single measure of prostate-specific antigen at or before age 50. Cancer 2011;117:1210-19. 
68. Vickers AJ, Ulmert D, Sjoberg DD, et al. Strategy for detection of prostate cancer based on relation between prostate specific antigen at age $40-55$ and long term risk of metastasis: casecontrol study. BMJ 2013;346:f2023.

Guideline author list: Neil Bell, Sarah Connor Gorber, Amanda Shane, Michel Joffres, Harminder Singh, James Dickinson, Elizabeth Shaw, Lesley Dunfield and Marcello Tonelli.

Affiliations: Department of Family Medicine (Bell), University of Alberta, Edmonton, Alta.; Public Health Agency of Canada (Connor Gorber, Shane, Dunfield), Ottawa, Ont.; Faculty of Health Sciences (Joffres), Simon Fraser University, Burnaby, BC; Departments of Internal Medicine and Community Health Sciences (Singh), University of Manitoba, Winnipeg, Man.; Departments of Family Medicine and Community Health Sciences (Dickinson) and Office of the Associate Dean - Research (Tonelli), University of Calgary, Calgary, Alta.; Department of Family Medicine (Shaw), McMaster University, Hamilton, Ont.

Contributors: Neil Bell, Sarah Connor Gorber, Amanda Shane, James Dickinson, Lesley Dunfield and Marcello Tonelli contributed substantially to the study concept and design, and the analysis and interpretation of the evidence, and drafted the manuscript. Michel Joffres contributed to the analysis and interpretation of data and revised the draft. Harminder Singh and Elizabeth Shaw contributed to the interpre- tation of data and revised the draft. All of the authors approved the final version of the manuscript and agree to act as guarantors of the work.

Funding: Funding for the Canadian Task Force on Preventive Health Care is provided by the Public Health Agency of Canada and the Canadian Institutes of Health Research. The views of the funding bodies have not influenced the content of the guideline; competing interests have been recorded and addressed. The views expressed in this article are those of the authors and do not represent those of the Public Health Agency of Canada.

Acknowledgements: The authors acknowledge Ali Usman and Donna Fitzpatrick-Lewis, members of the Evidence Review and Synthesis Centre research team who conducted the systematic review upon which these recommendations were based; the staff at the Prevention Guidelines Division and the Surveillance Division of the Public Health Agency of Canada; and the reviewers whose comments helped to improve the quality of this manuscript (Kami Kandola, Council of Chief Medical Officers of Health liaison representative; Scott D. Smith, College of Family Physicians of Canada; Anthony B. Miller, Dalla Lana School of Public Health, University of Toronto; Chris Del Mar, Bond University; Robert Nuttall, Canadian Cancer Society; Barbara Foster, Health Canada; Amanda Shaw, Public Health Agency of Canada; and Alexandra Barratt, School of Public Health, University of Sydney).

\title{
How you can get involved in the CMA!
}

The CMA is committed to providing leadership for physicians and promoting the highest standard of health and health care for Canadians. To strengthen the association and be truly representative of all Canadian physicians the CMA needs to hear from members interested in serving in elected positions and on appointed committees and advisory groups. The CMA structure comprises both governing bodies and advisory bodies either elected by General Council or appointed by the CMA Board of Directors. The Board of Directors - elected by General Council - has provincial/territorial, resident and student representation, is responsible for the overall operation of the CMA and reports to General Council on issues of governance.

CMA committees advise the Board of Directors and make recommendations on specific issues of concern to physicians and the public. Five core committees mainly consist of regional, resident and student representation while other statutory and special committees and task forces consist of individuals with interest and expertise in subject-specific fields. Positions on one or more of these committees may become available in the coming year.

For further information on how you can get involved please go to https://www.cma.ca/en/Pages/get-involved-in-cma.aspx, or contact

\author{
Cherise Araujo \\ Corporate and Governance Services \\ Canadian Medical Association \\ 1867 Alta Vista Drive, Ottawa ON K1G 5 W8 \\ Fax 613 526-7570, Tel 800 663-7336 x1949 \\ cherise.araujo@cma.ca
}

By getting involved, you will have an opportunity to make a difference.

We hope to hear from you!

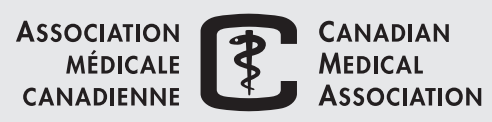

